\title{
STRUCTURING OF COLLAGEN OF THE DERMIS DURING RAWHIDE FORMATION
}

\author{
Anatoliy Danylkovych ${ }^{1, *}$, Viktor Lischuk ${ }^{2}$, Olexander Zhyhotsky ${ }^{3}$
}

DOI: dx.doi.org/10.23939/chcht11.01.081

\begin{abstract}
The research has been carried out to study colloid-chemical characteristics of stagewise formation of structured leather semi-finished product. It is established that the activity of basic chromium sulfate complexes increases significantly while transition from anion form to cation one. During plastication of dermis structure by alkyl carboxy ethanolamine tannins, diffusion of basic chromium sulfate complexes into dermis accelerates and therefore provides a high level of chemical structuring of collagen of the dermis. Environmentally-effective technologies were designed for chrome tanning in production of leather rawhide Wet-blue and non-chrome tanning for producing leather semi-finished products of polyfunctional application.
\end{abstract}

Keywords: rawhide, collagen of the dermis, structuring, tanning.

\section{Introduction}

In the multistage process of polyfunctional leather materials formation along with alkaline treatments of collagen-containing rawhide irreversible, mainly chemical structuring of dermis collagen plays a special role. This semi-finished product obtained is characterized by high resistance to moisture, chemicals, microorganisms, and mechanical influences. Dynamic porous structure of the semi-finished product is capable of evolutionary change in subsequent operations and processes of production cycle, which is the replacement of tanning solution to reagents that largely determine the functional properties of leather material. The efficiency of the structuring process of the collagen of the dermis significantly depends both on its

\footnotetext{
${ }^{1}$ Kyiv National University of Technologies and Design

2, Nemyrovych-Danchenko St., 01011Kyiv, Ukraine

${ }_{2}^{2}$ JSCo "Chinbar", 21 Kurenivska St., 04073 Kyiv, Ukraine

${ }^{3}$ Institute of Materials Science Problems named after I. M. Frantsevich,

2 Krzhyzhanovsky St., 03142 Kyiv, Ukraine

*ag101@ukr.net

(C) Danylkovych A., Lischuk V., Zhyhotsky O., 2017
}

colloidal chemical state and the chemical composition, structure and conditions of semi-finished product tanning

A wide range of chemicals is used for structuring of collagen of the dermis. On the one hand, the chemicals are supposed to provide necessary complex of physical and chemical properties of leather material and minimum negative effect of developed technologies on environment, on the other hand. In particular, this relates to tan compounds of chromium, which are used in large volumes and for which relatively low efficiency of application is observed (70-80\%) [1]. The need for its use is caused by the necessity to form leather material with high elasticplastic properties. This causes a large number of research studies in search of new effective reagents and conditions for their use in tanning technology. Along with compounds of chromium in structuring the collagen of the dermis mineral tanning compounds of aluminum(III), zirconium(IV), titanium(IV), and iron(II) [1, 2] as well as tannin, aldehydes, and derivatives of the compounds of the organic nature - naphthalene, polyphenols, and others are used $[3,4]$.

For providing a leather material with complex operating properties, considerable interest is focused on works on alternative methods of tanning $[2,5,6]$, which investigate the tannins combination of different composition. Thus, the use of alginic acid aldehyde with glutaraldehyde and oxazolidine tetractys oxymethyl phosphonium sulfate [5] provides higher physical and chemical properties of semi-finished product with hydrothermal stability of $370 \mathrm{~K}$ at reducing the content of hazardous substances in waste solutions. The work mentions that to obtain a material with high hydrothermal stability it is necessary to use at least two different nature reagents.

Significant increase of efficiency of chromium(III) compounds use in the reaction of structuring leather semifinished product may occur when chemical compounds are applied with active imino- and carboxyl groups [7]. In particular, it concerns microemulsion copolymer of butyl 
acrylate and monomers based on amino acids with the molecular weight of $6 \cdot 10^{5}$ and particle size of $40 \mathrm{~nm}$. This semi-finished product is characterized by hydrothermal resistance higher by 16 degrees compared to that of chrome tanning. Significant reduction of the content of chromium(III) compounds in tanning solution is achieved through vegetable tanning due to pretreatment of semifinished product by oxazolidinium and final treatment by chromium tanning agent.

The research papers $[9,10]$, in which the positive influence of the collagenase enzymes on the effectiveness of tanning of the leather semi-finished material has been observed, arouse interest. Thereby the effectiveness of the tanning agent using increases by $60 \%$, the hydrothermal stability of the semi-finished product increases and the duration of tanning decreases. It happens due to destroying of interfibrillar bonds, that intensifies the diffusion of tannins into the corium. The environmentally safe process of tanning of the semi-finished product is achieved due to the use of nano- $\mathrm{SiO}_{2}$ and enzymes. The stage of liming is excluded from the process [11]. It should be noted that the final semi-finished product with the hydrothermal stability temperature of $371 \mathrm{~K}$ without alkaline processing has high solidness but insufficient elasticity. Despite the fact that the composite tanning material synthesised on the basis of methacryloxypropyl silica, toxic anhydride and styrene in the toluene medium at $358 \mathrm{~K}$ in the presence of benzoyl peroxide with its following neutralization increases the temperature of hydrothermal stability and the thickness of the semifinished material by $17 \mathrm{~K}$ and $70 \%$, respectively [12], it does not contribute to the increase of the elastic leather material area, which limits its practical usage. Under the total excluding of chrome(III) compounds from the tanning process [13] it is impossible to obtain leather material with the complex of necessary elastically mouldable properties.

The influence of outer fields, namely the supersonic one [14, 15], and pressure [16] can contribute to the increase of the structuring process intensity. The comparative study of the semi-finished material tanning in static and dynamic conditions under the effect of supersonic energy has discovered considerably higher (almost 4 times) effectiveness in the first case. Carrying out the tanning process of the semi-finished material using chrome(III) compounds under the pressure up to $10 \mathrm{MPa}$ using $\mathrm{CO}_{2}$, as in the previous case, requires using of special equipment and implies additional expenses.

Taking into account the important role of the tanning process in technologies of leather materials production, a large amount of works, mainly of empirical character, uses a large variety of chemical agents for collagen of the dermis structuring. It is important to note rather small number of articles, in which colloid-chemical regularities and structural transformations of the semifinished product at this stage of the technological cycle are being observed. The variety of chemical composition and structure of the used agents stipulates the specific mechanism of their action in the process of obtaining the structured material that requires carrying out of systematic scientific research in this area, which can be used as the basis for development of scientifically grounded technologies of tanned semi-finished material production using chrome method - Wet-blue, combined methods, as well as leather materials of polyfunctional application.

In this article the investigation results about the action mechanism of the base chrome(III) sulphate, derivatives of ethanolamine and tannins of the pyrocatechine class (condensed) at the structuring of the corium collagen and designed technologies of the tanned semi-finished product are presented.

\section{Experimental}

For experiments the samples of the limed semifinished product have been used. The product was obtained by using previously developed technology of liming-soaking with the usage of the enzymatic drug during the stage of soaking, and sodium hydrosulphide, amine drug at the temperatures of 300-302 K during liming process, introduced at JSC "Chynbar". After washing and fleshing the halves of the semi-finished oxide with the thickness of $6.3-6.7 \mathrm{~mm}$ decreased by $2.4-3.0$ and $3.0-4.2 \mathrm{~mm}$ depending on the peculiarities of its structuring. Before tanning the halves of the semi-finished product underwent liming - softening treatment at the temperature of 307-309 K with the purpose of structured calcium transformation into solution, using ammonium sulphate, and further destroying of mucopolysaccharides bonds with collagen macromolecules under the effect of the enzyme protosubtilin G3x over anionic surfactant.

Non-chromed fibres (NCF) from skins of horned cattle have been used as a collagen specimen.

For the tanning of rawhide the following agents have been used:

- Base chrome sulphate (BCS) $\mathrm{Cr}_{2}\left(\mathrm{SO}_{4}\right)_{n}(\mathrm{OH})_{6-2 n}$;

- Tannins of mimosa and willow;

- Synthetic tanning agent BNS.

Alkylcarboxylethanolamines have been used as a regulating reagent of $\mathrm{BCS}$ interaction with collagen:

$\mathrm{HO}\left(\mathrm{CH}_{2}\right)_{2} \mathrm{NH}_{3}{ }^{+-} \cdot \mathrm{O}(\mathrm{O}) \mathrm{CR}_{2}$ 
where $\mathrm{R}$ - aliphatic acids radical of fraction $\mathrm{C}_{7}-C_{9}$ (ACEA AA) or naphthenic acid radical of gas-oil fraction (ACEA NK) containing 25-30\% of polycyclic acids and with average molecular weight 244 .

The study of interaction between corium collagen with ACEA and BCS were carried out on specimen systems using GP, which was modified in $0.8 \%$ solution of ACEA with the following GP ratio: the solution of the chemical agent 1:10 according to the weight with the following adding in half an hour of the same quantity of BCS with basicity $38 \%$ at 293 K. For GP patterns under the acid-saline processing the solution of $\mathrm{NaCl}$ and $\mathrm{H}_{2} \mathrm{SO}_{4}$ at 5.5 and $0.6 \%$ of GP watered volume, respectively, was used. After two hours from the beginning of the process $10 \%$ solution of $0.3 \% \mathrm{Na}_{2} \mathrm{CO}_{3}$ relative to the GP weight was added. The duration of the BCS processing is $5 \mathrm{~h}$.

In the process of semi-finished product tanning also $\mathrm{NaCl}, \mathrm{HCOOH}$ and $\mathrm{H}_{2} \mathrm{SO}_{4}$ have been used.

The $\mathrm{pH}$ testing of BCS water solutions and other tanning substances was conducted on pH-340 apparatus. The persorption of ACEA and BCS by corium collagen was analysed by means of gravimetrical and chemical methods, respectively [17]. The hydrothermal stability of the semi-finished product was evaluated by the temperature of shrinkage beginning of the model by heating it in water-glycerine mixture $T_{g l}$. The dependence of water vapours persorption by the semi-finished product, $W$, on their relative elasticity $\varphi$ was analysed at the temperature of $293 \mathrm{~K}$ according to the methods described in [18]. The dependence of the relative diffusion depth of the structuring agent $h$ on the duration of processing was analysed on the cross section of the model using optical method with the help of MBM-3 microscope.

The thermal and thermodynamic characteristics of the modified GP were analysed using the method of thermogravimetric analysis on the derivatograph OD-102 at the interval of temperatures $293-873 \mathrm{~K}$ at the heating rate of $10 \% \mathrm{~min}$ [19] in the helium atmosphere. The ordering effect of the GP collagen structure was evaluated according to enthalpy of melting $\Delta H$, taking into account the heating effect of the model - benzoic acid, and the total energy of destruction activation $E_{a}$, which characterises unsoundness of the supramolecular collagen structure, was calculated using Frieman-Carrol method [20]. The thermostability of GP was evaluated according to the weight lost heating at the temperatures up to $573 \mathrm{~K}$ $\left(\Delta m_{300}\right)$. The temperatures of the beginning and maximum of melting $T_{b m}$ and $T_{m m}$, respectively, the destruction beginning $T_{b d}$ and the maximum destruction speed $T m_{d}$ of the model testify the interaction intensity between macromolecules of GP collagen.

The electronic microscopy study of the rawhide structure was carried out due to raster-type electronic microscope PEMMA-102 [21]. The optimization of the tanning process with identification of the beneficial area of parameters of its control and the condition of the semifinished product have been carried out using compositional rotatable Box-Hunter plan of the second order and the Harrington's function [22].

\section{Results and Discussion}

\subsection{The mechanism of Interaction of Hydroxyl-Chromium Sulphate Complexes with Dermis Collagen}

For effective carrying out of the semi-finished product structuring process it is necessary to create availability and chemical activity of certain functional groups of the dermis collagen and the base chrome sulphate or other tanning agent. Depending on the chemical composition of the structuring agent it is necessary to activate groups of acidic and base character using chrome compounds or vegetable tanning agents. The fragment of the microfibril area [23] (Table 1) can give evidence about the peculiarities of the chemical composition of collagen of the dermis.

According to Table 1, collagen of the dermis on nanostructured level is characterized by the presence of amino acids of different chemical activity in the polypeptide chains of macromolecule, which varies depending on the environment $\mathrm{pH}$. The charges of the microfibril triads are located in its structural weaknesses unevenly, along which the links with structuring agent are formed. The centers of interaction are located in the lateral radicals of the polypeptide chains at different distances from it, due to their length, and form more accessible amorphous areas of microfibrils.

In the flooded state the intermolecular distances increase to $0.6-0.8 \mathrm{~nm}$ [23], and between the microfibrils to $2.7 \mathrm{~nm}$ [23]. Considering the size of hydroxyl chromium sulfate (HCS) complexes after the transition in cationic form $-0.7 \mathrm{~nm}$, we can assume that the structure of collagen of the dermis will be available to interact with BCS after the appropriate training. For larger particles of the structuring agents, their interaction with collagen of the dermis is on the micro fibrillar and fibrillar levels. 
The microfibril area

\begin{tabular}{|c|c|c|c|c|c|c|}
\hline \multirow{2}{*}{ Number of triad } & \multicolumn{5}{|c|}{ The number of the macromolecule fragment, which contains microfibril } & \multirow{2}{*}{ Charge } \\
\hline & 1 & 2 & 3 & 4 & 5 & \\
\hline 8 & $\begin{array}{c}\text { GG G } \\
\text { FFF } \\
\text { Q QQ }\end{array}$ & $\begin{array}{l}\text { G G G } \\
\mathbf{E} \mathbf{E} \mathbf{E} \\
\mathrm{P}^{\prime} \mathrm{P}^{\prime} \mathrm{P}^{\prime}\end{array}$ & $\begin{array}{l}\text { G G G } \\
\text { AA L } \\
\mathrm{P}^{\prime} \mathrm{P}^{\prime} \mathrm{P}^{\prime}\end{array}$ & $\begin{array}{l}\text { G G G } \\
K K K \\
\mathbf{E} \mathbf{E}\end{array}$ & $\begin{array}{l}\text { G G G } \\
\text { P P P } \\
\text { AAA }\end{array}$ & $\begin{array}{c}-3,+3 \\
-3\end{array}$ \\
\hline 9 & $\begin{array}{l}\text { GG G } \\
\text { P P P } \\
\mathrm{P}^{\prime} \mathrm{P}^{\prime} \mathrm{P}^{\prime}\end{array}$ & $\begin{array}{l}\text { GGG } \\
\text { AAP } \\
\text { P'P }^{\prime} \text { A }\end{array}$ & $\begin{array}{l}\text { G G G } \\
\text { P P P } \\
\text { S S A }\end{array}$ & $\begin{array}{l}\text { G G G } \\
\text { S S T } \\
K K K\end{array}$ & $\begin{array}{l}\text { G G G } \\
\text { P P P } \\
R R R\end{array}$ & +6 \\
\hline 10 & $\begin{array}{l}\text { G G G } \\
\mathbf{E} \mathbf{E} \mathbf{E} \\
\mathrm{P}^{\prime} \mathrm{P}^{\prime} \mathrm{P}^{\prime}\end{array}$ & $\begin{array}{l}\mathrm{GGG} \\
\mathrm{N} \mathrm{N} \mathrm{S} \\
K K K^{\prime}\end{array}$ & 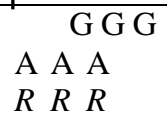 & $\begin{array}{l}\text { G G G } \\
\text { P P P } \\
R R R\end{array}$ & $\begin{array}{l}\text { G G G } \\
\text { P P P } \\
\text { P'P'A }^{\prime}\end{array}$ & +9 \\
\hline 11 & $\begin{array}{l}\text { G G G } \\
\mathbf{E} \mathbf{E} \mathbf{E} \\
\mathrm{P}^{\prime} \mathrm{P}^{\prime} \mathrm{P}^{\prime}\end{array}$ & $\begin{array}{l}\text { GG G } \\
\text { D DE } \\
\text { T T S }\end{array}$ & $\begin{array}{l}\text { G G G } \\
\mathbf{E ~ E ~ E ~} \\
R R R\end{array}$ & $\begin{array}{l}\text { G G G } \\
\text { E E D } \\
\text { T T Q }\end{array}$ & $\begin{array}{l}\text { G G G } \\
\text { S S P } \\
\text { AAS }\end{array}$ & $\begin{array}{c}-12 \\
+3\end{array}$ \\
\hline
\end{tabular}

Note: the notation of amino acids according to IUPAC: glycine $-\mathrm{G}$, phenylalanine $-\mathrm{F}$, glutaminic acid $-\mathrm{E}$, alanine $-\mathrm{A}$, leucine $-\mathrm{L}$, lysine $-\mathrm{K}$, proline $-\mathrm{P}$, glutamine $-\mathrm{Q}$, hydroxyproline $-\mathrm{P}^{\prime}$, serine $-\mathrm{S}$, arginine $-\mathrm{R}$, asparagine $-\mathrm{N}$, hydroxylysine $\mathrm{K}^{\prime}$, asparagines acid $-\mathrm{D}$, threonine $-\mathrm{T}$; the lines on the right indicate stable areas of triads.

Considering the characteristics of the complex structure of BCS it is possible to regulate its activity in the interaction with collagen of the dermis. The results of the research process of BCS dissolution in water showed a significant decrease in $\mathrm{pH}$ solution, which is especially intense during the first $10 \mathrm{~min}$ (Fig. 1). Moreover, this effect is more clearly seen at a higher temperature of experiment.

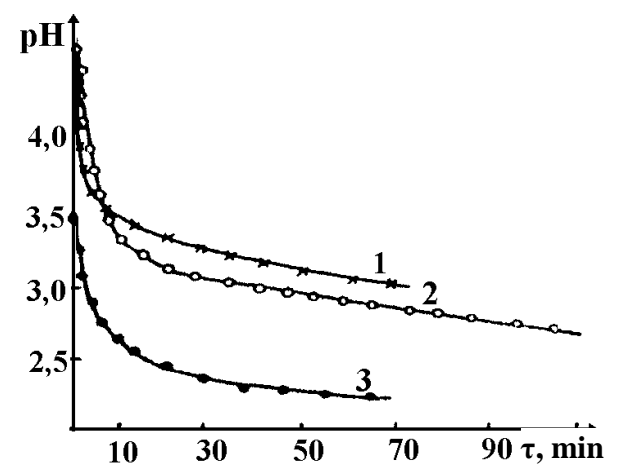

Fig. 1. Kinetics of $\mathrm{pH}$ change at $\mathrm{BCS}$ dissolving with different concentration, $\mathrm{g} / \mathrm{dm}^{3}: 40$ (1) and $10(2,3)$ at $293 \mathrm{~K}(1,2)$ and $310 \mathrm{~K}$

The process of dissolving BCS may occur according to the following reaction:

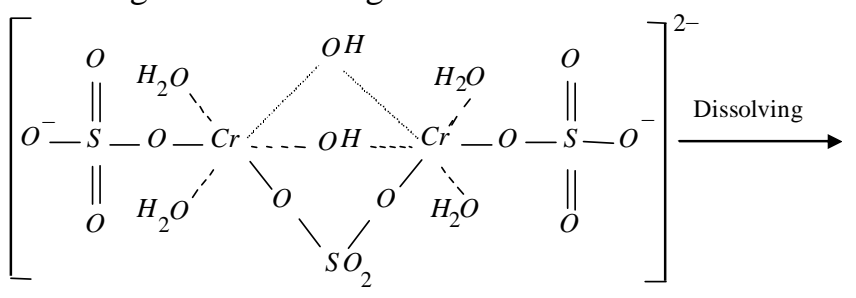

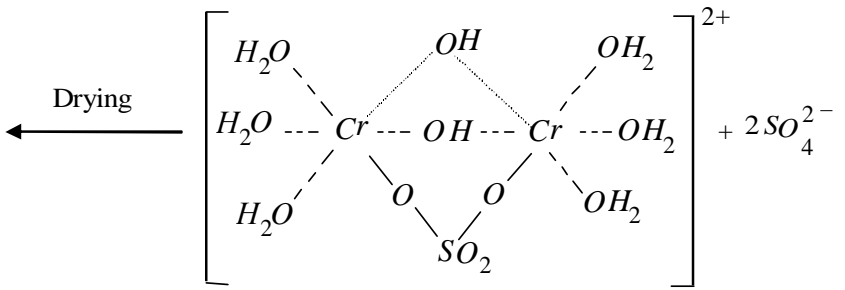

Thus there is a transition of sulphate groups from the inner sphere of the anionic form complexes to the outer one, as a result of their displacement with water molecules. It results to the creation of cation form of HCS complexes with a decrease of its activity at $\mathrm{pH}$ decrease. At higher $\mathrm{pH}$ the nuclearity of HCS complexes increases as a result of process flowing of chrome complexes bond through interaction of hydroxyl groups with their following condensation [25] and creation of bonds with participation of sulphate groups:<smiles>O1[GeH2]O[GeH2]1</smiles>

Considering the location of the carboxyl groups and the distance between them in the microfibril of collagen with the volume $1 \mathrm{D}$, that corresponds to a displacement of one macromolecule toward another by $67 \mathrm{~nm}$ [26], the possible types of relationships were examined, that form HCS complexes with neighboring macromolecules of single-level or adjacent triads - type 1 and after one or two type 2 and through the macromolecule and one or two triads type 3 (Fig. 2).

If two carboxyl groups interact with one molecule of di-nuclear HCS complex or the one of higher nuclearity then bonds of 1 and 3 types in collagen derma can be 
created according to distance between ionized carboxyl groups. At the beginning of collagen interacting with dinuclear HCS complexes bonds of 1-type are created. If $\mathrm{pH}$ increases, the size of chrome complexes increases due to hydrolysis of BCS, which promotes creation of bonds 2 and 3 types. The possible quantity of created outer- and innermicrofibriled bonds is given in Table 2 .

While calculating the quantity of possible bonds of HCS complexes with collagen it was taken into account that the number of carboxyl groups in volume 1D of microfibril that can interact is 226 . The quantity of possible bonds of type 1 is $61 \%$ and of type $2-73 \%$, which is due to more advantageous geometrical position of carboxyl groups to create the bonds of this type. Actually there will be less carboxyl groups in comparison to quantity of bonds of type 1 , as the bonds of types 2 and 3 are created after gradual increase of technologic solution $\mathrm{pH}$ to 4.2-4.4 at an increase of basicity of HCS complexes and accelerated structuring of dermis collagen. $5.5 \mathrm{~g}$ of di- nuclear complexes are required on condition that there is $100 \%$ participation in interaction of carboxyl groups of collagen with HCS complexes if there is bond of one carboxyl group of one atom of chrome on $100 \mathrm{~g}$ of collagen. In practice, the quantity of chrome complexes that effectively take part in chemical structuring of collagen of the dermis meets $60-65 \%$ of general quantity of carboxyl groups in collagen.

The increase of basicity and quantity of HCS complexes that interact with derma collagen helps to increase its hydrothermal persistency, which changes symbatically with the effectiveness of interaction and degree of structuring (Table 3). The effect of basicity on hydrothermal persistency is observed while interacting on the first stage of di-nuclear HCS complexes structuring. It should be noted that hydrothermal persistency of semi-finished product has the maximum rating when the nuclearity of GSX complexes is increased to $12 \mathrm{~h}$, and so it depends on the kinetics of their interaction with derma collagen.

\begin{tabular}{|c|c|c|c|c|}
\hline G G G & G G G & G GG & G GG & G G G \\
\hline $\mathrm{F} \mathrm{F} \mathrm{F}$ & $3 R C O Q$ & A A L & K K K & P P P \\
\hline Q Q Q & $\mathrm{P}^{\prime} \mathrm{P}^{\prime}, \mathrm{P}^{\prime}$ & $\mathrm{P}^{\prime} \mathrm{P}^{\prime} \mathrm{P}^{\prime}$ & $3 R \mathrm{COO}^{-}$ & A A A \\
\hline G G G & $\mathrm{G}, \dot{\mathrm{G}} \mathrm{G}$ & 'G G G & G GG & G G G \\
\hline $\mathrm{P} P \mathrm{P}$ & $A^{* A} P$ & $P$ P.P & $\mathrm{S} \mathrm{S} \mathrm{T}$ & P P P \\
\hline $\mathrm{P}^{\prime} \mathrm{P}^{\prime} \mathrm{P}^{\prime}$ & $\mathrm{P}^{\prime} \mathrm{P}^{\prime} \mathrm{A}$ & $S$ S A. 3 & K K K & R R \\
\hline $\mathrm{G} \mathrm{G} \mathrm{G}$ & $G G G$ & $\mathrm{G} G \mathrm{G}$ & $\mathrm{G} G \mathrm{G}$ & G G \\
\hline $3 \mathrm{RCOO}$ & N N S & A A A & P P P & $\mathrm{PP}$ \\
\hline $\mathrm{P}^{\prime} \mathrm{P}^{\prime} \mathrm{P}^{\prime}$ & ${ }^{\prime} \mathrm{K}$ K K' & R R R & $R \cdot R \quad R$ & $\mathrm{P}^{\prime} \mathrm{P}^{\prime} \mathrm{A}$ \\
\hline $\mathrm{G} G \mathrm{G}$ & $G^{\prime} \mathrm{G}^{\circ} \mathrm{G}$ & $\mathrm{G} G \mathrm{G}$ & $\mathrm{G} \mathrm{G}^{\prime} \mathrm{G}$ & G G G \\
\hline $3 \mathrm{RCOO}^{-}$ & $3 R C O O^{-}$ & $3 \mathrm{RCOO}-$ & $3 R \mathrm{COO}^{-}$ & S S P \\
\hline $\mathrm{P}^{\prime} \mathrm{P}^{\prime} \mathrm{P}^{\prime}$ & $\mathrm{T} T \mathrm{~T}$ & R R R & $\mathrm{T} \mathrm{T} \mathrm{O}$ & A A \\
\hline
\end{tabular}

Fig. 2. Possible interactions of BCS complexes in collagen microfibil

Table 2

The quantity of possible bonds of HCS complexes in 1D volume of collagen microfibril

\begin{tabular}{|c|c|c|c|}
\hline \multirow{2}{*}{ Bond type } & \multirow{2}{*}{ Distance, nm } & \multicolumn{2}{|c|}{ Quantity of bonds } \\
\cline { 3 - 4 } & & inner & outer \\
\hline 1 & $0.6-0.8$ & 27 & 42 \\
\hline 2 & $0.8-1.4$ & 29 & 54 \\
\hline 3 & $>1.4$ & 27 & 45 \\
\hline
\end{tabular}

Table 3

Hydrothermal persistency of derma collagen under the effect of HCS complexes

\begin{tabular}{|c|c|c|c|c|}
\hline \multicolumn{2}{|l|}{ HCS complexes } & \multirow{2}{*}{$\begin{array}{c}\mathrm{Cr}_{2} \mathrm{O}_{3}, \% \text { in semi-finished } \\
\text { product }\end{array}$} & \multicolumn{2}{|c|}{$T_{g l}$ collagen, $\mathrm{K}$} \\
\hline $\begin{array}{c}\mathrm{Cr}_{2} \mathrm{O}_{3}, \% \text { relative to green semi-finished } \\
\text { product weight }\end{array}$ & Basicity, \% & & after stabilization & after $12 \mathrm{~h}$ \\
\hline 1.1 & 34.0 & 3.47 & 374 & 378 \\
\hline 1.2 & 42.0 & 3.78 & 377 & 380 \\
\hline 1.3 & 34.0 & 4.12 & 380 & 384 \\
\hline 1.3 & 26.0 & 4.89 & 379 & 386 \\
\hline
\end{tabular}


The results of sorptive research of semi-finished product structure change show the effective interaction of HCS complexes with derma collagen (Fig. 3). The character of form change of sorption isotherm of water steam can indicate wide division of pore sizes in the samples researched and its sorption grows in the area of capillary condensation. At the beginning of sorption isotherms are characterized by linear dependency of moisture content $W$ in the samples from gauge pressure till 0.1-0.2. Hysteresis on the sorption-desorption curves shows the bigger value of water left during desorption and it indicates high hygroscopicity of derma collagen at different processing stages. The maximum point of quantity of water steam sorption by derma collagen of structured HCS complexes rises to $17 \%$ comparing to the samples of bacterial treatment. It shows the decrease of concentration of collagen hydrophilic group as a result of their active interaction with HCS complexes and intermolecular bonds creation. It should be noted that the hydrophility of structured derma collagen is high and moisture content in it will decrease during further technological processing.

To provide the effective diffusion of HCS complexes into derma structure it is necessary to decrease the activity of carboxyl groups of collagen macromolecules by decreasing $\mathrm{pH}$ or their temporary blocking. The results of thermogravimetric (Fig. 4, Table 4) show that derivates are characterized by the presence of two endometric effects that are mixed in a considerable temperature interval. The first endometric effect refers to the process of melting of crystal parts of collagen and the second one to its thermal destruction. Thermodynamic and thermic characteristics show that after salt and acid processing the firmness of samples of destruction is lower.

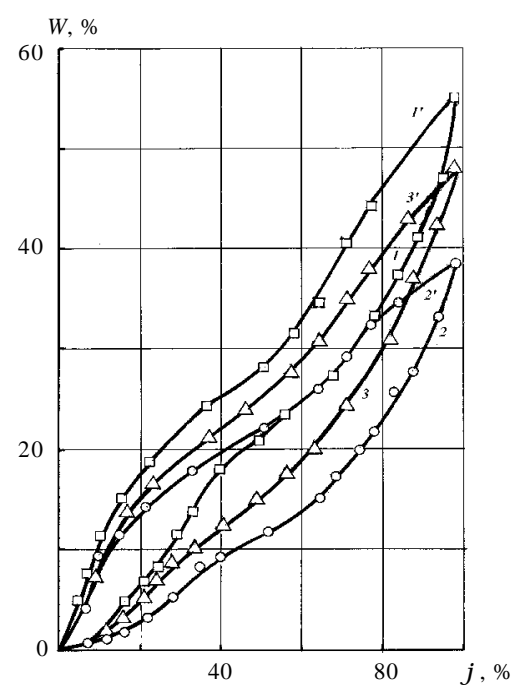

Fig. 3. Isotherms of water steam sorption (1-3) and desorption $\left(1^{\prime}-3^{\prime}\right)$ by samples after treatment by: alkaline $\left(3,3^{\prime}\right)$; enzyme $\left(1,1^{\prime}\right)$ and HCS complexes $\left(2,2^{\prime}\right)$
After salt and acid processing the thermodynamic and thermic characteristics decrease but loss of mass and speed of destruction of the samples increase comparing with the yield of GP. It indicates the lower thermal firmness of collagen to destruction. This effect can be determined by partial dehydration of structural elements of derma collagen as a result of osmotic effect of free fluid collagen macromolecules transition into salt solution that fill the interstructural space starting from intermacromolecular ones. In this process interstructural space is increased.

Unlike salt and acid processing after modification by GP ACEA, temporary blocking of carboxyl groups of collagen of the dermis takes place and is accompanied by basic ACEA groups and its structural plasticizing influence on intermacromolecule interaction in collagen. It can be seen in rising of modified GP. The next processing of powder of GP HCS both after salt and acid modification and ACEA is accompanied by rising of thermal and thermodynamic indicators of structured samples as a result of interaction of HCS complexes with ACEA and collagen creating chemical space bonds between carboxylic groups of neighbouring polypeptide chains of biopolymer.

The processing of BCS of previously modified ACEA GP is accompanied by increase of rating of thermodynamic characteristics comparing to GP of previous processing. It can show an active effect of ACEA on increase of structuring activity of HCS complexes. More proportional diffusion of HCS complexes into microfibrils of collagen is possible as a result of extra interaction of ACEA molecules with derma collagen.

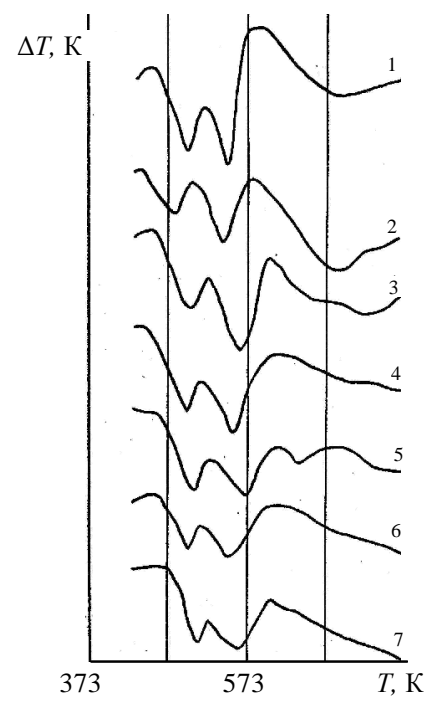

Fig. 4. Thermograph of GP: without processing (1); acid-salt processing (2); acid-salt + BCS (3); ACEA NA (4); ACEA $\mathrm{NA}+\mathrm{BCS}$ (5), ACEA AA (6); ACEA AA + BCS (7) 
Table 4

Thermodynamic and thermal indicators of GP modified by ACEA

\begin{tabular}{|c|c|c|c|c|c|c|c|}
\hline \multirow{2}{*}{ Processing GP } & \multicolumn{2}{|c|}{ Melting temperature, $\mathrm{K}$} & \multirow{2}{*}{$\Delta H, \mathrm{~kJ} / \mathrm{kg}$} & \multicolumn{2}{|c|}{ Temperature of destruction, $\mathrm{K}$} & \multirow{2}{*}{$\Delta m_{300}, \%$} & \multirow{2}{*}{$E_{a}, \mathrm{~kJ} / \mathrm{mo}$} \\
\hline & $T_{b m}$ & $T_{m m}$ & & $T_{b d}$ & $T_{m d}$ & & \\
\hline Without processing & 454 & 497 & 25.8 & 514 & 551 & 20.8 & 109 \\
\hline Acid-salt & 448 & 485 & 46.6 & 502 & 546 & 22.1 & 85 \\
\hline Acid-salt + BCS & 458 & 503 & 46.5 & 522 & 557 & 19.2 & 118 \\
\hline ACEA NA & 452 & 492 & 50.7 & 512 & 553 & 21.1 & 107 \\
\hline ACEA NA + BCS & 463 & 506 & 43.2 & 525 & 565 & 14.8 & 127 \\
\hline ACEAAA & 453 & 494 & 51.5 & 513 & 551 & 21.4 & 104 \\
\hline ACEAAA + BCS & 476 & 508 & 44.8 & 523 & 561 & 16.7 & 122 \\
\hline
\end{tabular}

The properties of rawhide structured BCS with the availability of ACEA

Table 5

\begin{tabular}{|c|c|c|c|c|c|c|}
\hline \multirow[t]{2}{*}{ Hide processing } & \multirow{2}{*}{$\begin{array}{c}\text { ACEA } \\
\text { concentration, } \mathrm{g} / \mathrm{dm}^{3}\end{array}$} & \multirow{2}{*}{$\begin{array}{c}\text { BCS } \\
\text { sorption, \% }\end{array}$} & \multirow{2}{*}{$\begin{array}{l}\mathrm{Cr}_{2} \mathrm{O}_{3} \text { mass } \\
\text { fraction, } \%\end{array}$} & \multirow[t]{2}{*}{$\alpha$} & \multicolumn{2}{|c|}{$\begin{array}{c}T_{h s} \text { of collagen after processing, } \\
\mathrm{K}\end{array}$} \\
\hline & & & & & ACEA & BCS \\
\hline \multirow{4}{*}{ ACEAAA } & 13.0 & 82.0 & 4.5 & 0.68 & 63.0 & 98.0 \\
\hline & 24.0 & 88.0 & 4.8 & 0.85 & 62.0 & 112.0 \\
\hline & 35.0 & 94.0 & 5.1 & 0.89 & 61.0 & 117.0 \\
\hline & 46.0 & 87.0 & 4.6 & 0.83 & 60.0 & 109.0 \\
\hline \multirow{4}{*}{ ACEA NA } & 13.0 & 86.0 & 4.7 & 0.71 & 63.0 & 102.0 \\
\hline & 24.0 & 92.0 & 5.0 & 0.92 & 62.0 & 118.0 \\
\hline & 35.0 & 89.0 & 4.8 & 0.87 & 61.0 & 109.0 \\
\hline & 46.0 & 83.0 & 4.4 & 0.81 & 59.0 & 106.0 \\
\hline Acid-salt & - & 43.0 & 2.4 & 0.59 & $48.0^{1}$ & 77.0 \\
\hline Without processing & - & 74.0 & 4.0 & 0.43 & 64.0 & 87.0 \\
\hline
\end{tabular}

Note: ${ }^{1} T_{h s}$ of semi-finished product after acid-salt processing

The results of the research of hydrothermal stability of rawhide depending on ACEA concentration in the working solution show the plastifying effect of ACEA on the structure of collagen of the dermis during its structuring (Table 5). As seen from the data received, $T_{h s}$ and BCS sorption by semi-finished product after ACEA processing and HCS complexes have the extreme rating depending on the ACEA content in technological solution when indicator values of acid-salt processing are low. Moreover, uniformity ratio of chrome compounds distribution in derma layers is lower than in semi-finished product while using ACEA. It can indicate that the previous ACEA processing of semi-finished product before its structuring provides a high uniformity of the process of collagen interacting with ACEA and BCS complexes.

When the amount of ACEA is small, some $T_{h s}$ dermis reduction is observed. Thus evident stretch effect is seen, caused by partial destruction and corresponding weakening of interchain hydrogen coupling with little destabilization of the collagen structure, which contributes to easier diffusion of HCS complexes in the volume of the dermis and the formation of more chemical bonds of type
1-3. With increasing concentration of ACEA, stretch effect is enhanced resulting in stronger destabilization of the collagen structure, which manifests itself in further reducing of its $T_{h s}$ and BCS sorption after reaching the extreme value.

A significant increase of collagen $T_{h s}$ observed in the ternary system is caused by the interaction of the carboxyl groups of the collagen with ACEA at the beginning of its treatment by solution and BCS stabilized by ACEA, which contributes to reduction of the activity of HCS complexes on the first stage of collagen structure stabilization and facilitates the diffusion of ACEA BCS complexes into its microfibrillar structure with further manifestation on the second stage of trans effect of monoethanolamine ACEA interacting with chromium cation in the top of his field. There is a domination of the interaction forces between chromium cations located nearby, and ionized carboxyl groups of collagen over the forces of interaction between these groups and free ACEA. As a result of competitive interaction collagen carboxyl groups are in near-field chromium(III) complex, thus pushing addendum, placed in transconfiguration, relative to the cycle, formed by monoethanolamine cation ACEA. 
Trans-effect of monoethanolamine ACEA contributes to joining ionized carboxyl groups of collagen in the near field of chromium complexes and coordination bonds formation between them. In excess ACEA compared to the optimal number, significant decrease appears in BCS activity due to reinforced complexation of its particles with this reagent and transition of stabilized chromium complexes in neutral with the reduction of chemical activity, accompanied by a decrease of semi-finished product $T_{h s}$.

Thus, the use of ACEA in prestable processing of semi-finished products makes it possible to process stabilization of collagen structure of the dermis and the formation of complexes using BCS with reduced basicity. The use of low basic capacity complexes provides a necessary $\mathrm{pH}$ value of environment for effective structuring and stabilization of semi-finished product.

\subsection{Interaction of Tannins and Rawhide}

Environmental requirements for modern technologies lead to hazardous chemicals and materials usage reduction in manufacturing processes. In this regard, promising technologies of rawhide processing is the use of structuring agents of plant origin tannin, which can form a large number of hydrogen bonds with the amino groups of collagen macromolecules and effectively fill the microscopic pores in the structure of the dermis and act as active filler. Since the size of the tannin particles is much larger compared to HCS complexes [27], we can expect a low rate of diffusion in rawhide structure (Fig. 5). To a large extent this explains the need to fix the structures of the dermis collagen by low molecular weight

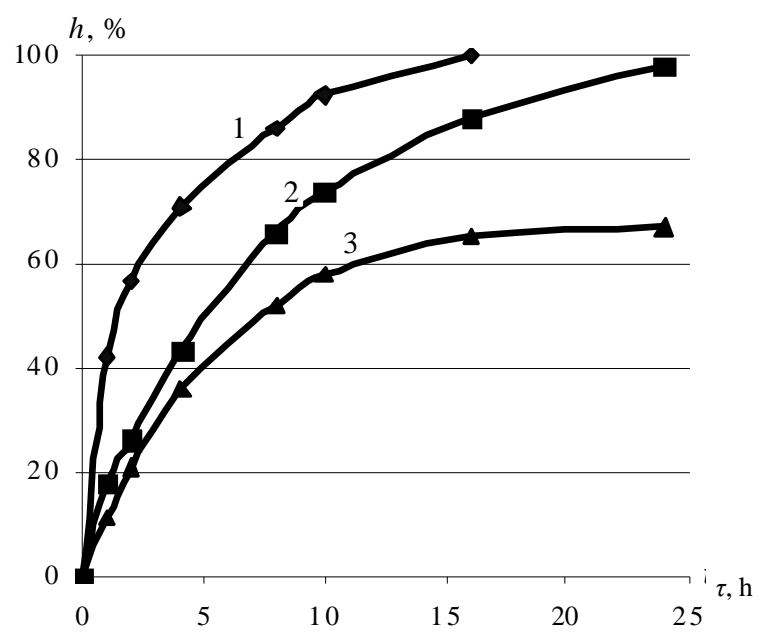

Fig. 5. Kinetics of diffusion in structured semi-finished product by BCS complexes of tannins: mimosa: $\mathrm{BNS}=4: 1$ (1); mimosa (2) and willow (3) agents, including BCS, formaldehyde, sodium polyphosphate and others [28].

According to the results of the study of vegetable tannins diffusion in the semi-finished product $3.0 \mathrm{~mm}$ in thickness, pre-structured HCS complexes at the rate of $1.0 \mathrm{wt} \% \mathrm{Cr}_{2} \mathrm{O}_{3}$ relative to semi-finished product (Fig. 5), the minimum rate of particles diffusion is observed in the case of willow tannins, the maximum for a mixture of mimosa tannins and synthetic tannin BNS. In the first case tannins penetrate at the depth of only $66 \%$ of the semifinished product thickness during $24 \mathrm{~h}$, while tannins mixed with synthetic tanning materials diffuse throughout the semi-finished product during $16 \mathrm{~h}$. Intermediate value takes mimosa tannins that penetrate the semi-finished product during $24 \mathrm{~h}$. The obtained data show smaller particles of mimosa tannins in comparison with willow tannins. A significant increase in the rate of tannin diffusion and possible structuring acceleration of the semi-finished products with the use of synthetic tannin BNS is caused by its effect on particles of vegetable tannins and decrease in their size.

The study of influence of vegetable tannin type on structuring of the semi-finished product (Fig. 6) shows that pre-stabilized structure of semi-finished product HCS complexes to $T_{h \mathrm{~s}}=357 \mathrm{~K}$ due to the interaction with plant tannins of a polyphenolic type is characterized by its increase. The dependence of $T_{h s}$ on structuring duration is adequate to diffusion kinetics of vegetable tannins in the semi-finished structure. The maximum effect of structuring is observed using a mixture of mimosa tannin and synthetic tanning materials BNS. It is important to note that less diffusion depth and less willow tannin effect of their interaction with dermis collagen is accompanied with a slight increase in $T_{h s}$ due to tannin banding with microfibrillas in the surface layers of the semi-finished products.

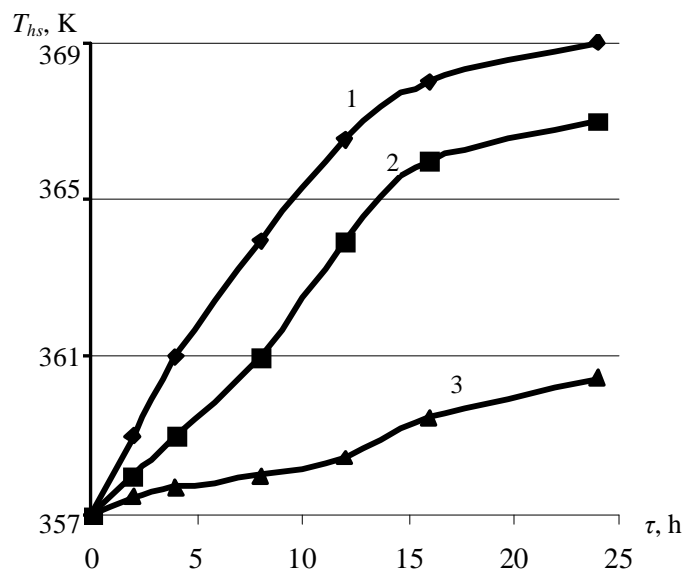

Fig. 6. Dependence of $T_{h s}$ of semi-finished product structured by HCS complexes on interaction period with tannins:mimosa:BNS = 4:1 (1); mimosa (2) and willow (3) 


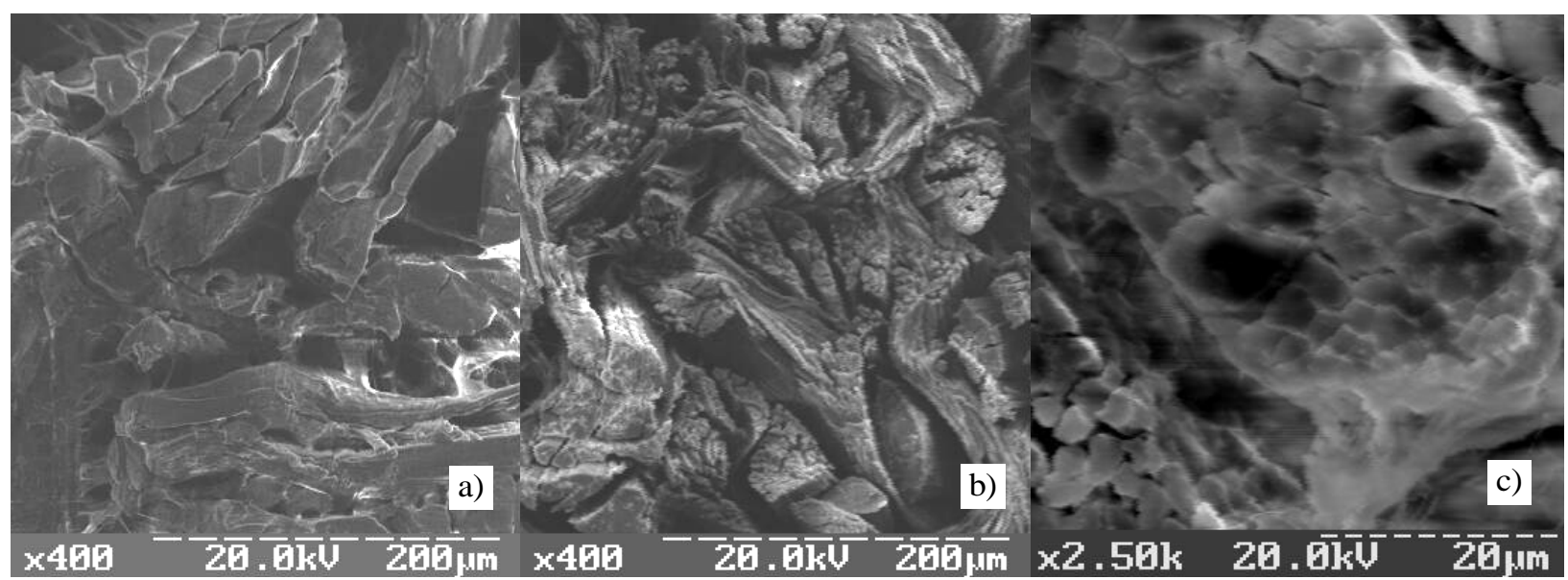

Fig. 7. Submicroscopical images of cross-section of the semi-finished product during softening (a);

BCS tanning (b) and synthetic treatment (c)

Table 6

Characteristics of tanning technologies of leather semi-finished product

\begin{tabular}{|l|c|c|c|c|c|}
\hline \multirow{2}{*}{ Index } & \multicolumn{4}{|c|}{ Tanning technologies } \\
\cline { 2 - 6 } & \multirow{2}{*}{ CTNS } & \multirow{2}{*}{ DSCT } & \multirow{2}{*}{ SCMS } & \multicolumn{2}{c|}{ Control } \\
\cline { 2 - 6 } & & & Chrome & CST \\
\hline Consumption rate of OCX, \% of limed semi-finished product mass & 4.4 & 5.2 & 1.6 & 8.8 & 2.4 \\
\hline - AKEA & 0.6 & 0.7 & 3.0 & - & - \\
\hline - Sodium chloride & 2.5 & 4.0 & 4.5 & 6.0 & 6.0 \\
\hline - Water & 20 & 40 & $50 / 120$ & 70 & $100 / 120$ \\
\hline - Mimosa extract & - & - & 10 & - & 12 \\
\hline OCX basicity, \% & 33.0 & 34.0 & 40.0 & $38-42$ & $38-42$ \\
\hline Total time, h & 6.0 & 11.0 & 24.0 & 18.0 & $10 / 42$ \\
\hline OCX absorption, \% of the original mass & 96.5 & 93.2 & 98.0 & 75.6 & 89.3 \\
\hline Hydrothermal resistance, $\mathrm{K}$ & 107.0 & 106.0 & 85.0 & 104.0 & 87.0 \\
\hline Chromium compound content, \% $\mathrm{Cr}_{2} \mathrm{O}_{3}$ of oven-dry mass & 3.9 & 4.1 & - & 4.6 & - \\
\hline Output area, \% raw hide area & 93.0 & 94.0 & 97.0 & 87.0 & 95.0 \\
\hline Consumption of energy, $\mathrm{kW}$ & 42.0 & 66.0 & 144.0 & 108.0 & 196.0 \\
\hline
\end{tabular}

Note: ${ }^{1}$ the duration of preparation for synthetic tanning

The evolution of structural changes of dermis collagen involving HCS complexes and vegetable tannins is well displayed on cross-section microimages of the semi-finished product in various stages of treatment (Fig. 7). As can be seen from Fig. 7a, bundles of fibers of the collagen of the dermis after enzymatic treatment of delimed semi-finished product are connected in structural elements of larger sizes; the pores being evident between them.

During acid-salt treatment followed by dermis collagen structuring by HCX complexes, the division of bundles of fibers into elementary fibers begin to appear (Fig. 7b) with an increase in pores quantity and a decrease in their size. After synthetic structuring of the dermis collagen due to precipitation of tannin particles on the surface of bundles of fibers, the features of studied structure of samples are not appeared clearly, even at 2500x zoom (Fig. 7c). At the same time large pores remain visible.

Thus, the obtained results in accordance with the diffusion kinetics of mixture of mimosa tannins and synthetic tanning material BNS in 4:1 ratio and reached relatively high hydrothermal stability of structured dermis collagen and electron-microscopic research give reason for the use of synthetic and vegetable tanning in leather treatment technologies of the semi-finished products.

\subsection{Tanning Technologies of Leather Semi-Finished Product}

Taking into account the peculiarities of structuring process of unhaired semi-finished product using tanning compounds of different chemical composition in the implementation of appropriate technologies will deter- 
mine the effectiveness of the following treatments taking into account the specific features of the previous treatment and leather material forming of different functional purposes. In turn, the rational use of chemicals must be connected with the structure of semi-finished leather product and depend on the innovation level of used technology.

Based on the previous set of scientific and technological researches a number of optimized technologies of chrome method of tanning of the dermis collagen with obtaining a semi-finished leather product Wet-blue [29] and using compounds of synthetic nature and vegetable tannins was developed. The effectiveness of the developed technologies is testified by the results of their comparison with the previously existing industrial technologies at JSC "Chinbar" chrome [30] and chromesynthetic (CST) tanning [31]. Comparative characteristics of developed technologies are given in Table 6. In developed tanning technologies HCS complexes of anionic form were used [32, 33], while cationic form of tannins was used in control tanning. Technology of non-split semi-finished product chrome tanning (CTNS) involves the use of anionic forms of basic chromium sulphate during tanning of semi-finished product to $3.0 \mathrm{~mm}$ in thickness after liming, softening with enzyme agent and processing with alkyl carboxy ethanolamine emulsion processing for $0.5 \mathrm{~h}$ followed by the addition of $\mathrm{NaCl}$ at $291-293 \mathrm{~K}$ and drum rotation at the speed of $8-9 \mathrm{~min}^{-1}$. Tanning is performed on the developed technological solution.

Technology of chrome tanning method of unsplit semi-finished product (CTUS) unlike CTSS technology implies the use of rawhide of over $3.0 \mathrm{~mm}$ in thickness after softening and salting of semi-finished product by $\mathrm{NaCl}$ concentration of $250 \mathrm{~g} / \mathrm{l}$ and followed by acid-salt treatment. For this purpose, formic $(85 \%)$ and sulphuric $(100 \%)$ acids are used $(0.25$ and 0.5 of the limed semifinished product mass, respectively). After work solution is drained out from the rotary machine ACEA is added and drum rotation is prolonged by $5 \mathrm{~h}$.

Technology of synthetic tanning of semi-finished product (SVST) requires two times as continuous alkaline treatment for deeper loosening of its fibrous structure of the semi-finished product caused by the use of tanning agents with larger particle size. To ensure effective tannin diffusion into the structure of semi-finished product $2.4 \mathrm{~mm}$ in thickness, after its acid-salt treatment it is structured by BCS with significantly less consumption, compared to chrome tanning technologies. Before synthetic tanning the semi-finished product has been processed on a new solution with BNS synthetic tannin (consumption $2.5 \%$ per tannins from the mass of semifinished products) for $1 \mathrm{~h}$, emulsive ACEA and its subsequent structuring by vegetable tanning agent.
Comparative analysis of chrome tanning and previously existing technologies shows significant reduction of BCS, sodium chloride and water consumption. Moreover, these technologies provide considerable reduction in the duration of treatment with corresponding savings in electricity. Environmentally safer SVST technology provides significantly lower costs of chromium compounds. This is due to lower $T_{h s}$ of tanned rawhide compared to CTT technologies. However, this technology provides the highest output area of hide that is used to make certain range of footwear products. Due to efficient use of chromium compounds in chrome and synthetic tanning these technologies belong to environment-friendly and energy saving.

\section{Conclusions}

Comprehensive study of the effect of tanning compounds of different chemical nature on the process of structuring collagen of the dermis made it possible to establish the mechanism of interaction of chromium compounds and alkyl carboxy ethanolamine and specifics of the use of tannins. It was established that the activity of basic chromium sulfate systems is increased significantly during transition from anionic to cationic form. These dinuclear complexes of chromium(III) diffuse into the structure while collagen structuring due to their nanoscale diffuse in structure of the dermis, reaching polypeptide chains of collagen microfibrils to form coordination with the participation of ionized carboxyl groups of side radicals of its macromolecules. While plastifying structure of the dermis by alkyl carboxy ethanolamine due to the temporary blocking of active functional collagen groups, diffusion of basic chromium sulfate complexes into the dermis increases, that ensures their effective participation in the structuring process.

It has been shown that efficient use of tannins in rawhide tanning is ensured after previous interaction of dermis collagen with basic chromium sulfate complexes and disaggregation of particles of tanning agents while using synthetic tanning agent. Research of hydrophilic semi-finished product in the process of technological treatments of semi-finished product shows considerable reduction of rather high level of content of technological solution at chemical structuring, which is going to reduce dynamically during further treatments connected with substitution of technological solutions of reagents in leather semi-finished product.

The developed technologies for tanning intermediate product from rawhide, as compared to previously existing technologies at JSC "Chinbar", are characterized by $1.7-2.2$ and 4.0 time reduced consumption of chromium(III) compounds for leather materials of chrome 
and synthetic tanning, respectively. At the same time the duration of the process cycle of chrome tanning process is reduced by 1.6 and 3.0 times with corresponding reduction of power consumption. Effectiveness of the use of Wet-blue semi-finished product obtaining technology depends significantly on the kind of rawhide, primarily on its surface and thickness. Significant reduction of chromium compounds in waste solutions after tanning gives grounds to include developed technology to ecoefficient ones. In particular, it concerns the technology of synthetic tanning. With that, this technology provides the highest saving of scarce raw hides by maximizing the output area of the material. The technology of Wet-blue semi-finished product obtained from different kinds of rawhide at JSC "Chinbar", corresponding to international standard ISO 9001:2008 "Quality Management System. Requirements" expand the range of leather materials of polyfunctional application.

\section{References}

[1] Surkova A., Abdullin I., Zhuravlev B., Parsanov Y.: Vestnik Kazan. Technol. Univ., 2009, 6, 91.

[2] Hui C., Jun G. and Zhihua S.: J. Amer. Leather Chem. Assoc., 2011, 106, 18.

[3] Covington D., Song L, Suparno O. et al.: World Leather, 2010, 23, 35 .

[4] Pustylnik J.: Kozha i Obuv, 2008, 3, 22.

[5] Jayakumar G, Bala L., Kanth I. et al.: J. Amer. Leather Chem. Assoc., 2011, 106, 50.

[6] Covington A.: J. Amer. Leather Chem. Assoc., 2008, 103, 7.

[7] Kanagaraj J., Gupta S., Baskar G. and Reddy B.: J. Amer. Leather Chem. Assoc., 2008, 103, 36.

[8] das Gupta S.: J. Amer. Leather Chem. Assoc., 2009, 104, 92.

[9] Kanth S., Kannan P., Usharani N. et al.: J. Amer. Leather Chem. Assoc., 2010, 105, 16.

[10] Kanth S., Kannan P., Usharani N. et al.: J. Amer. Leather Chem. Assoc., 2009, 104, 405.

[11] Liu Y., Chen Y., Yao J. et al.: J. Amer. Leather Chem. Assoc., 2010, 105, 84.

[12] Pan H., Qi M. and Zhang Z.: Chin. Chem. Lett., 2008, 19, 435.

[13] Krishnaraj K., Thanikaivelan P. and Chandrasekaran B.: J. Amer. Leather Chem. Assoc., 2010, 105, 71.

[14] Morera J., Bartoli E., Serrano M. et al.: J. Amer. Leather Chem. Assoc., 2010, 105, 150.

[15] Morera J., Bartoli E., Combalia F. et al.: J. Amer. Leather Chem. Assoc., 2010, 105, 369.

[16] Renner M., Weidner E. and Brandin G. Chem. Eng. Res. Des., 2009, 87, 987.

[17] Danylkovych A. G.: Praktykum z Khimii ta Technologii Schkiry ta Hutra. Fenix, Kyiv 2006.

[18] Greg S. and Syng K.: Adsorbcia, Udelnaya Poverchnost, Poristost. Mir, Moskva 1984.
[19] Paulik F., Paulik J. and Erdey L.: Zeitschrift für analytische Chemie, 1958, 160, 241.

[20] Rabek Ya.: Eksperymentalnye Metody v Khimii Polymerov. Mir, Moskva 1983.

[21] Gouldstein Dzh., Nyubery D., Echlyn P. et al.: Rastrovaya Elektronnaya Microskopiya i Rentgenovskiy Microanaliz. Mir, Moskva 1984.

[22] Achnazarova S. and Kafarov V.: Metody Optimizacii Experimenta v Khimicheskoi Technologii. Vysh. schkola, Moskva 1985.

[23] Lishchuk V., Danylkovych A. and Zhegotski O.: Lehka Prom., 2011, $2,27$.

[24] Heidemann E.: Das Leder, 1995, 46, 149.

[25] Mikhailov A.: Kolagen Kozhnogo Pokrova i Osnovy ego Pererabotky. Legkaya ind., Moskva 1971.

[26] Nikitin V., Persky E. and Utevskaia L.: Vozrastnaya i Evolutsionnaya Biokhimiya Collagenovych Struktur. Naukova dumka, Kyiv 1977.

[27] Mikhailov A.: Khimya Dubyashchich Veshchestv i Protsesov Dubleniya. Gizlegprom, Moskva 1953.

[28] Danylkovych A.: Nauk. Visnyk PUSKU, 2009, 1, 52.

[29] Danylkovych A.: Formuvannja i Stabilizacja Structury Dermy [in:] Danylkovych A. (Ed.), Ekologichno Orientovani Technologii Vyrobnyctva Shkirianykh ta Hutrovykh Materialiv dlia Stvorennia Konkurentospromozhnykh Tovariv. Feniks, Kyiv 2011, 134-265.

[30] Metodyka Proizvodstva Kozh Hromovogo Dublennya Raznykh Tolschyn i Assortymenta dlya Verkha i Podkladki Obuvi, Galantereinykh Izdeliy iz Shkur Krupnogo Rogatogo Skota. Kyiv 1992.

[31] Metodyka Vyrobnytstva Iuhty Vzuttevoi Khromsyntanroslynnogo Dublennya z Shkur Velykoi Rogatoi Hudoby na Kyivskomu Orendnomu Pidpryemstvi «Chynbar». Kyiv 1992.

[32] Danylkovych A. and Sidliar Iu.: Pat. UA 36805A, Publ. Apr. 16, 2001.

[33] Danylkovych A. and Sidliar Iu.: Pat. UA 36806A, Publ. Apr. 16,2001 .

Received: April 07, 2015 / Revised: M ay 18, 2015 / Accepted: N ovember 01, 2015

\section{СТРУКТУРУВАННЯ КОЛАГЕНУ ДЕРМИ ПРИ ФОРМУВАННІ ШКІРЯНОГО НАПІВФАБРИКАТУ}

Анотація. Досліджено колоїдно-хімічні особливості постадійного формування структурованого шкіряного напівфабрикату. Встановлено, що активність гідроксосульфатохромових комплексів суттєво підвищується при переході аніонної в катіонну форму. При пластифікаиї структури дерми алкілкарбоксиетаноламінами прискорюється дифузія гідроксосульфатохромових комплексів у дерму, що забезпечує високий рівень хімічного структурування колагену дерми. Розроблені екологічно ефективні технології хромового дублення у виробництві шкіряного напівфабрикату Wet-bluе $i$ безхромового дублення для виготовлення икіряних матеріалів поліфункиіонального призначення.

Ключові слова: шкіряний напівфабрикат, колаген дерми, структурування, дублення. 
